\title{
Simulation Vacuum Preloading Method by Tri-Axial Apparatus
}

\author{
Ngo Trung Duong ${ }^{1}$, Wanchai Teparaksa ${ }^{1}$, Hiroyuki Tanaka ${ }^{2}$ \\ ${ }^{1}$ Department of Civil Engineering, Faculty of Engineering, Chulalongkorn University, Bangkok, Thailand \\ ${ }^{2}$ Faculty of Engineering, Hokkaido University, Sapporo, Japan \\ Email: ngotrungduong@yahoo.com,wanchai.te@chula.ac.th,tanaka@eng.hokudai.ac.jp
}

Received October 25, 2011; revised December 14, 2011; accepted January 13, 2012

\begin{abstract}
It is very important to control any risk of instability of embankment during vacuum construction, the simulation vacuum preloading method using tri-axial apparatus is proposed to predict the behavior of soft soil improvement in the laboratory, as well as to make this method become familiar and easier in the future. The tri-axial apparatus is used instead of the large-scale one, which has been performed by Bergado (1998) and Indaratna (2008). The tri-axial test on small size specimen can be carried out in one week compared to the large-scale apparatus takes one month for big specimen. In addition, the lateral deformation as well as the shear strength increase with time can determine accurately.
\end{abstract}

Keywords: Soft Soil; Soil Improvement; Vacuum Preloading; Degree of Consolidation

\section{Introduction}

Nowadays the vacuum preloading consolidation method becomes the popular method to improve soft soil. This method is an effective method of improving soft soil conditions as introduced by Kjellman (1952) [1] in early 1952. With the merging of new materials and technologies, this method has been further improved in recent years.

The modeling vacuum method to improve soft soil in the laboratory has been performed by Indaratna 2008 [2] using the large-scale apparatus and follows one-dimensional consolidation theory (Tezaghi). The results obtained from this modeling partially evaluated the behavior of soft soil reinforced by vacuum preloading method in the laboratory. Using the large specimen $45 \mathrm{~cm} \times 90$ $\mathrm{cm}$ in diameter and height respectively in the large-scale apparatus, the time used for this test was more than one month.

The horizontal deformation $\varepsilon_{\mathrm{r}}$ during the tested time, which is the typical deformation of soft soil improvement by vacuum, and also the increasing of shear strength could not be measured. So far, the controlling surcharge processing during vacuum construction has not been discussed sufficiently.

The new method is proposed using tri-axial apparatus to simulate the comprehensive behavior of soil improvement by vacuum preloading method in the laboratory to support the engineering task quickly. In addition, it is desired to make the method become familiar in the fu- ture.

The finite element method (FEM) is used to analyze two cases of drainage condition at the boundary and center of the axisymmetric soil cell.

The study aspects to solve these matters are as follows:

1) Simulation the behavior of soft soil improved by vacuum method by tri-axial apparatus under axisymetric consolidation condition;

2) The lateral deformation and vertical settlement are concerned during soil improvement by vacuum preloading method;

3) Evaluating the degree of consolidation during soil improvement;

4) Combination surcharge and vacuum preloading to estimate the increasing shear strength).

\section{Tri-Axial Apparatus}

Tri-axial apparatus can clearly evaluate the failure mechanism as well as the capacity of increasing shear strength of soil in the laboratory. From the tri-axial test, the result parameters are used to predict the behavior of soil in the field during construction.

Under vacuum pressure condition alone, the soil mass at depth is subjected the isotropic stress status $(\mathrm{K}=1)$. With flexible functions of the tri-axial machine as shown in Figure 1, the isotropic condition of the soil mass can generate the same vacuum condition by controlling the lateral earth pressure (K).

During vacuum condition, the surcharge loading can 


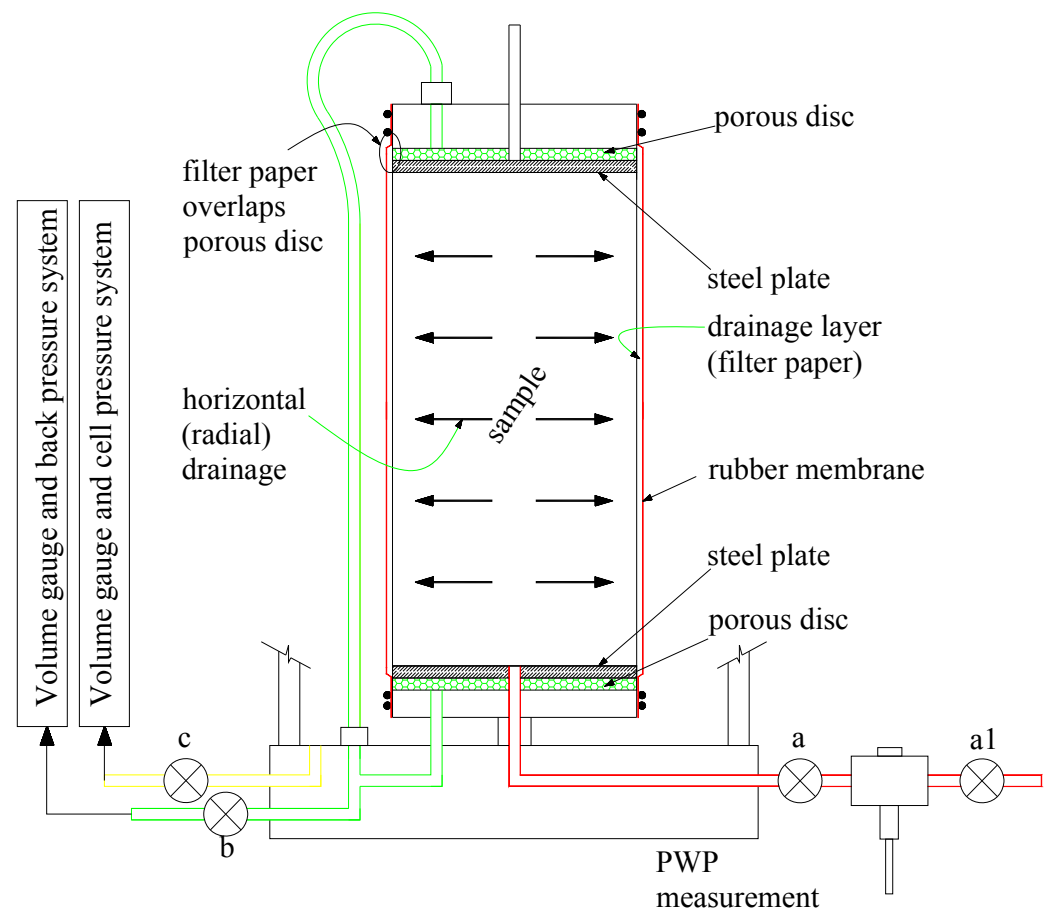

Figure 1. Scheme tri-axial apparatus.

be generating as axial force by the loading rod at top of the machine. The deformations of soil specimen in vertical and horizontal direction are measured during testing to evaluate the behavior of soil specimen.

The specimen is covered by rubber membrane and placed in the water tank; therefore the friction between circular soil specimen and the cell is eliminate, which is different to the oedometer apparatus.

The steel plates at the ends of specimen are as the impervious layer, only radial drainage is induced during consolidation. The filter paper covers around the boundary of specimen and overlaps the porous discs at the both ends of specimen as the drainage layer. For the largescale oedometer apparatus, the drainage was established at the center of specimen. The FEM has been used to define the different between the drainage path conditions of specimen, and defines the correction factor for this simulation. The boundary conditions were illustrated in the Figure 2.

The assumptions were used for simulation of vacuum preloading method are as follow:

1) Soil mass as subjected vacuum pressure follows axisymmetric consolidation.

2) Under vacuum pressure only, soil mass will be subjected the Isotropic stress state, it mean that the coefficient of horizontal earth pressure $(\mathrm{K})$ equal to one, while for the surcharge only $(\mathrm{K})$ value can calculate from Equation (1).

3) For the soil mass, the vacuum pressure is distributed along to the specimen is uniform.

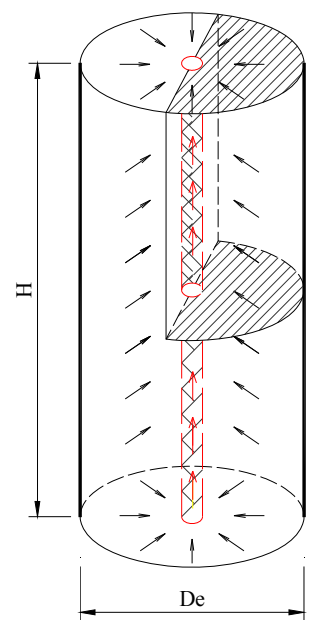

(a) Drainage at center

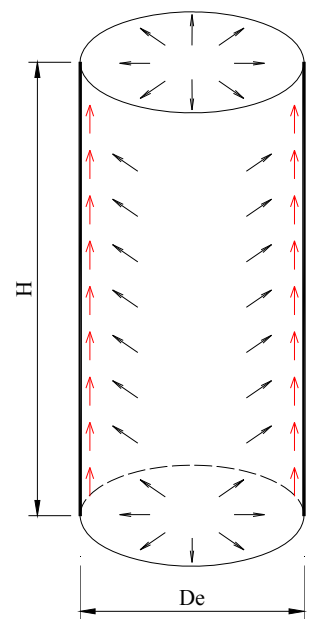

(b) Drainage at outer boundary
Figure 2. The drainage condition of axisymetric cell.

$$
\mathrm{K}=1-\sin \varphi
$$

where $\varphi$ : the friction angle of soil.

\section{Finite Element Method of Analysis for Drainage Boundary Condition Analysis}

\subsection{Thetheory of Asixmetric Consolidation}

The unit cell theory representing a single circular drain surrounded by a soil annulus in an axisymmetric condition has been used (e.g. Barron, 1948; Yoshikuni and Nakanodo, 1974; Hansbo, 1981). Most researchers ac- 
cepted that under embankment loading, the single drain analysis could not provide an accurate prediction due to lateral yield and heave compared to plane strain multidrain analysis (Indraratna, et al., 1997) although the degree of consolidation (DOC) in this model is acceptable accuracy.

In this topic, the method is proposed to model the behavior of soft soil improvement by vacuum combine with surcharge preloading method while the lateral displacement is concerned during consolidation.

The following assumptions are based on Hansbo solution (1981) about equal strains $(\varepsilon)$, the variation of the permeability $(\mathrm{k})$ when void ratio (e) decrease during consolidation and the volume compressibility $\left(\mathrm{m}_{\mathrm{v}}\right)$.

1) Soil is homogeneous and fully saturated; the Darcy's law is adopted. Depend on the purposes the outer boundary of unit cell the drainage path is occurred.

2) Soil strain is uniform at the boundary of the unit cell and the small strain theory is valid, therefore Hooke's law should be applied for calculation.

3) For the mass soil, the vacuum pressure distribution along to the drain boundary is uniform during application.

The accuracy of the FE analysis was checked against the analytical solutions of Barron (1948) and Hansbo (1981) [3]. According to Barron (1948) [4], the degree of consolidation U for "equal-strain" consolidation is given in Equation (2).

$$
\mathrm{U}=1-\exp \left(-\frac{8 \mathrm{~T}}{\mu}\right)
$$

with

$$
\begin{gathered}
\mu=\left(\frac{\mathrm{n}^{2}}{\mathrm{n}^{2}-1}\right) \ln \mathrm{n}-\frac{3 \mathrm{n}^{2}-1}{4 \mathrm{n}^{2}} \\
\mathrm{n}=\frac{\mathrm{D}_{\mathrm{e}}}{\mathrm{D}_{\mathrm{w}}}
\end{gathered}
$$

where $D_{e}$ and $D_{w}$ are diameters of unit cell and equivalent of vertical drain respectively. Hansbo (1981) introduced a circular smear zone (of diameter $\mathrm{D}_{\mathrm{s}}$ ) in the solution which resulted in a modified expression for $\mu$

$$
\begin{gathered}
\mu=\ln \left(\frac{\mathrm{n}}{\mathrm{m}}\right)+\frac{\mathrm{k}_{\mathrm{ho}}}{\mathrm{k}_{\mathrm{hs}}} \ln \mathrm{m}-\frac{3}{4} \\
\mathrm{~m}=\frac{\mathrm{D}_{\mathrm{s}}}{\mathrm{D}_{\mathrm{w}}}
\end{gathered}
$$

For two dimensional consolidation $U(\%)$ can be expressed in terms of integrals of the excess pore water pressure over the unit cell domain as Madhav et al. 1993.

$$
U=1-\frac{\iint_{\mathrm{y}} \mathrm{u}(\mathrm{x}, \mathrm{y}, \mathrm{T}) \mathrm{dxdy}}{\iint_{\mathrm{y} x} \mathrm{u}_{0} \mathrm{dxdy}}
$$

where $\mathrm{u}(\mathrm{x}, \mathrm{y}, \mathrm{T})=$ excess pore water pressure at any point with $\mathrm{x}, \mathrm{y}$ dimension at a time factor $\mathrm{T}$, and $\mathrm{u}_{\mathrm{o}}$ is the initial excess pore water pressure.

Terzaghi-Rendulic proposed differential equation for two-dimensional consolidation as

$$
\begin{gathered}
\frac{\partial \mathrm{u}}{\partial \mathrm{T}}=\mathrm{d}_{\mathrm{e}}^{2}\left(\frac{\partial^{2} \mathrm{u}}{\partial \mathrm{x}^{2}}+\frac{\partial^{2} \mathrm{u}}{\partial \mathrm{y}^{2}}\right) \\
\mathrm{T}=\frac{\mathrm{C}_{\mathrm{h}} \cdot \mathrm{t}}{\mathrm{D}_{\mathrm{e}}^{2}}
\end{gathered}
$$

where

$\mathrm{C}_{\mathrm{h}}$ : horizontal coefficient of consolidation.

As the strains are small, if E' is Young's modulus for effective stress, n' is Poisson's ratio for effective stress and the material is isotropic, Hooke's law is

$$
\left\{\begin{array}{l}
\delta \varepsilon_{\mathrm{r}} \\
\delta \varepsilon_{\theta} \\
\delta \varepsilon_{\mathrm{z}}
\end{array}\right\}=\frac{1}{\mathrm{E}^{\prime}}\left\{\begin{array}{ccc}
1 & -v^{\prime} & -v^{\prime} \\
-v^{\prime} & 1 & -v^{\prime} \\
-v^{\prime} & -v^{\prime} & 1
\end{array}\right\}\left\{\begin{array}{l}
\delta \sigma_{\mathrm{r}}^{\prime} \\
\delta \sigma_{\mathrm{r}}^{\prime} \\
\delta \sigma_{\mathrm{r}}^{\prime}
\end{array}\right\}
$$

where:

$\{\mathrm{r}, \mathrm{q}, \mathrm{z}\}$ is the principal axes set.

$\left\{\varepsilon_{\mathrm{r}}, \varepsilon_{\mathrm{q}}, \varepsilon_{\mathrm{z}}\right\}$ are the strain in radial, circumferential and vertical respectively.

The coefficient of consolidation $\mathrm{C}_{h}$ in the horizontal direction for axisymmetric plane strain deformation is showed as:

$$
\mathrm{C}_{\mathrm{h}}=\frac{\left(1-v^{\prime}\right) \mathrm{E}^{\prime}}{\left(1+v^{\prime}\right)\left(1-2 v^{\prime}\right)} \frac{\mathrm{k}_{\mathrm{h}}}{\gamma_{\mathrm{w}}}=\frac{\mathrm{k}_{\mathrm{h}}}{\mathrm{m}_{v} \gamma_{\mathrm{w}}}
$$

where

$\mathrm{k}_{\mathrm{h}}$ : horizontal hydraulic conductivity

$\gamma_{w}$ : unit weight of water

Dummy research, for the axisymetric unit cell the coefficient of volume compressibility $\left(\mathrm{m}_{\mathrm{v}}\right)$ varies during consolidation; $\mathrm{m}_{\mathrm{v}}$ value calculate by expression:

$$
\mathrm{m}_{\mathrm{v}}=\frac{\Delta \varepsilon_{v}}{\Delta \sigma_{\mathrm{a}}^{\prime}}
$$

where:

$\varepsilon_{\mathrm{v}}:$ volume strain of specimen

$\sigma_{\mathrm{a}}^{\prime}$ : is the axial effective stress at time reach to degree of consolidation.

\subsection{Solution for Axisymetric Unit Cell under Vacuum Pressure}

An axisymetric system of clay unit cell is used to model the behavior of soil specimen improved by vacuum preloading method.

The unit cell with size $7.5 \mathrm{~cm} \times 15.0 \mathrm{~cm}$ in diameter $\left(\mathrm{D}_{\mathrm{e}}\right)$ and height $(\mathrm{H})$ respectively $(\mathrm{H}=2 \mathrm{D})$, the effective Young's modulus E' $=500 \mathrm{kN} / \mathrm{m}^{2}$, Poisson's ration $\mathrm{v}^{\prime}=$ $0.33, \lambda=0.55, \kappa=0.06$, the horizontal and vertical 
hydraulic coefficient $\mathrm{k}_{\mathrm{h}}=\mathrm{k}_{\mathrm{v}}=4.66 \mathrm{E}-10 \mathrm{~m} / \mathrm{sec}$ and the ratio $\mathrm{n}=\mathrm{D}_{\mathrm{e}} / \mathrm{D}_{\mathrm{w}}$ from 10,20 are used to analyze. $\mathrm{D}_{\mathrm{w}}$ is equivalent diameter of vertical drain as in the Figure 3.

Three cases of axisymetric unit cells under vacuum preloading only as the Figure 3 were conducted to verify the relationship about degree of consolidation in the different boundary and drainage condition.

The first case, the outer boundary is fixed and drainage occurs at the center (FC) of unit cell. This is the conventional model to estimate the consolidation of axisymetric unit cell, which has been conducted by several researchers before such as Indraratna (2005) [5], Chai (2006) [6], Tran (2007) [7]. One-dimensional consolidation theory is used for this case. As we know that, this case is very suitable for both cases the surcharge loading only and the vacuum zone is infinite. Therefore, this method should not apply well for vacuum preloading.

The second and the third case are proposed to verify the consolidation of axisymetric unit cell under vacuum preloading in term of the lateral displacement as well as two-dimensional consolidation is concerned, the outer boundary of specimen is free or none $(\mathrm{N})$ combines drainage condition at the center (NC) and the outer boundary of unit cell (NB).

The series of case studies for axisymetric unit cell were conducted by FEM with Camclay Model, which shown in the Table 1. The cases from N1 to N12 are to check the accuracy of FEM analysis with vary ratio (n) in 10 and 20 with vacuum pressure applied of $50 \mathrm{kPa}$ and $100 \mathrm{kPa}$ respectively.

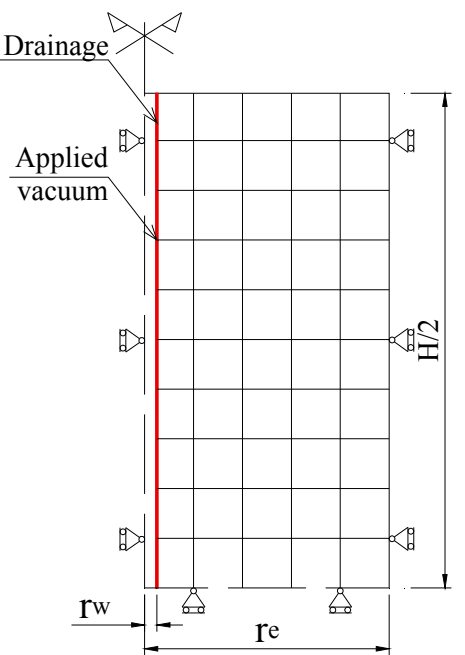

(a) Fixed boundary (FC)

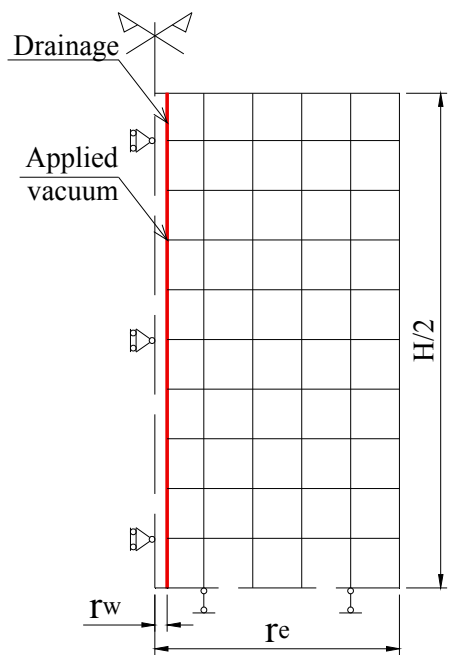

(b) Free boundary (NC)

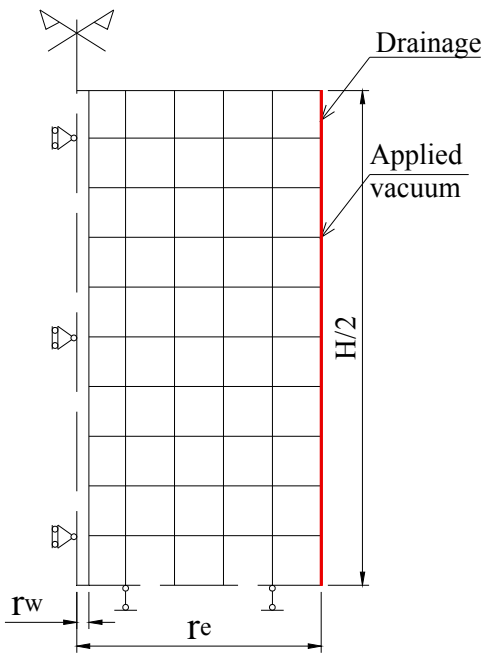

(c) Free and drainage at boundary (NB)

Figure 3. The modeling of axisymetric cell.

Table 1. The case studies for axisymetric unit cell.

\begin{tabular}{|c|c|c|c|c|c|c|}
\hline No & Case & Boundary condition & Drainage condition & Ratio $\mathrm{D}_{\mathrm{e}} / \mathrm{D}_{\mathrm{w}}$ & Vacuum pressure $(\mathrm{kPa})$ & DOC (U\%) \\
\hline N1 & FC-1-50 & Fixed & Center & & \multirow{6}{*}{50} & \multirow{6}{*}{$100 \%$} \\
\hline $\mathrm{N} 2$ & NC-1-50 & Free (None) & Center & $\mathrm{n}=10$ & & \\
\hline $\mathrm{N} 3$ & NB-1-50 & Free & Boundary & & & \\
\hline N4 & FC-2-50 & Fixed & Center & \multirow{3}{*}{$\mathrm{n}=20$} & & \\
\hline N5 & NC-2-50 & Free & Center & & & \\
\hline N6 & NB-2-50 & Free & Boundary & & & \\
\hline N7 & FC-1-100 & Fixed & Center & \multirow{3}{*}{$\mathrm{n}=10$} & \multirow{6}{*}{100} & \multirow{6}{*}{$100 \%$} \\
\hline N8 & NC-1-100 & Free & Center & & & \\
\hline N9 & NB-1-100 & Free & Boundary & & & \\
\hline N10 & FC-2-100 & Fixed & Center & \multirow{3}{*}{$\mathrm{n}=20$} & & \\
\hline N11 & NC-2-100 & Free & Center & & & \\
\hline N12 & NB-2-100 & Free & Boundary & & & \\
\hline N13 & NC-2-50-1 & Free & Center & \multirow{4}{*}{$\mathrm{n}=20$} & \multirow{4}{*}{50} & $\mathrm{U}=70 \%$ \\
\hline N14 & NC-2-50-2 & Free & Center & & & $\mathrm{U}=40 \%$ \\
\hline N15 & NB-2-50-1 & Free & Boundary & & & $\mathrm{U}=70 \%$ \\
\hline N16 & NB-2-50-2 & Free & Boundary & & & $\mathrm{U}=40 \%$ \\
\hline
\end{tabular}


The result presents the relationship between three cases boundary and drainage condition of specimen. (FC), (NC) and (NB). The other cases (case N13 to N16) are to estimate applicable surcharge preloading during vacuum procedure.

Comparisons were made for the cases of fix and none fix the outer boundary with ratio $\mathrm{n}=10, \mathrm{n}=20$ and vacuum pressure only $\mathrm{Va}=50 \mathrm{kPa}, \mathrm{Va}=100 \mathrm{kPa}$. The results of DOC (U\%) and Time factor $\mathrm{T}_{\mathrm{h}}$ from the FEM were found to compare well with the analytical solutions Baron (1948) [4] as show in the Figures 4-7.

The maximum difference in $U$, for $U>50 \%$, was about $0.26 \%$, occurring at $T=0.5$ for the case $n=10$ as shown in Figures 4 and 6. Forthe case $n=20$, the maximum difference in $\mathrm{U}$ was $0.17 \%$, occurring at $\mathrm{T}=0.5$ as shown in Figures 5 and 7.

Conclusion the degree of consolidation in both cases fixed boundary (FC) and free boundary (NC) are almost same value and agree strongly with Baron's theory (1948).

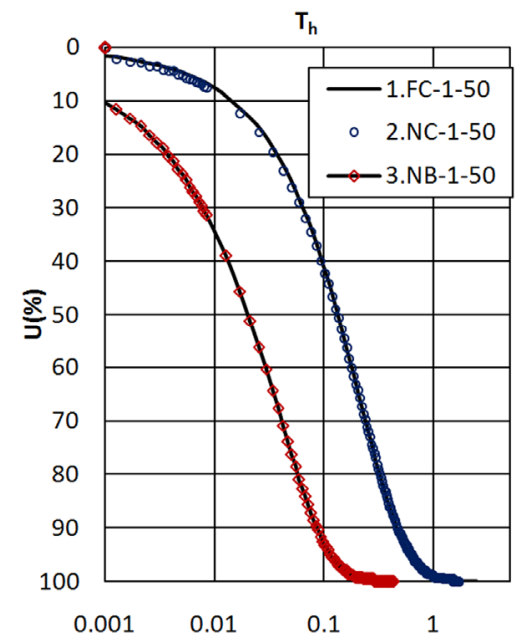

Figure 4. Case $n=10$, vacuum only; $\mathrm{Va}=50 \mathrm{kPa}$.

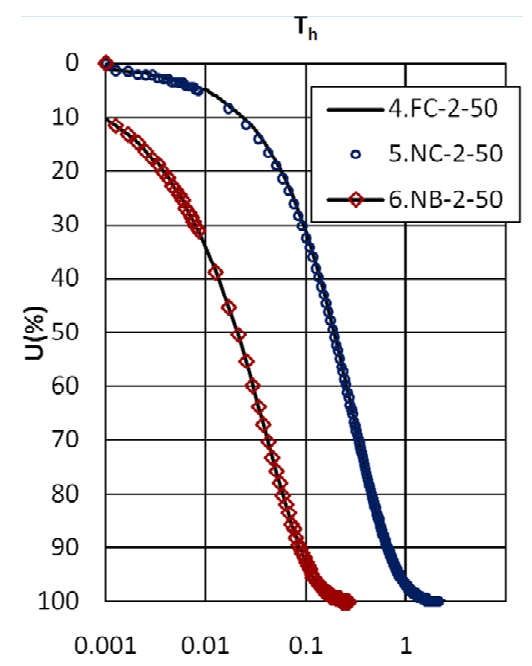

Figure 5. Case $\mathrm{n}=20$, vacuum only; $\mathrm{Va}=50 \mathrm{kPa}$.

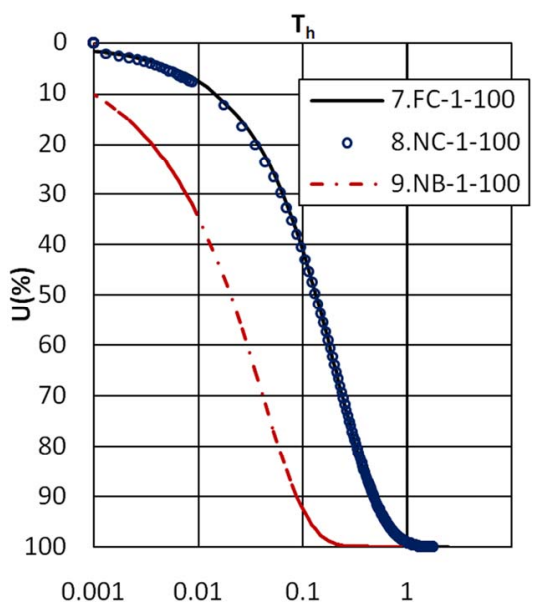

Figure 6. Case $n=10$, vacuum only; $\mathrm{Va}=100 \mathrm{kPa}$.

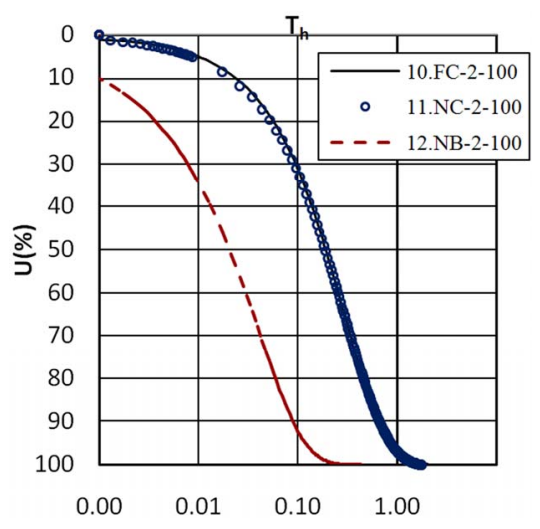

Figure 7. Case $n=20$, vacuum only; $\mathrm{Va}=100 \mathrm{kPa}$.

For the cases none outer boundary and drainage at the outer boundary (NB), degree of consolidation are almost same in both case $n=10$ and $n=20$ as during vacuum preloading.

The Figure 8 and Table 2 show the relationship between the modeling of axisymetric unit cell in free boundary condition, drainage at the center (NC) and at the boundary (NB) during vacuum stage.

As the same DOC, the average ratio of time factor for drainage at the center and outer boundary is $\mathrm{T}_{\mathrm{hNC}} / \mathrm{T}_{\mathrm{hNB}}$ about 6.7 and 9.7 for $n=10$, and $n=20$ respectively as showed from case N01 to N12.

The consolidation procedure of unit cell in (NB) case is faster than $(\mathrm{NC})$ case by ratio $\left(\mathrm{T}_{\mathrm{hNC}} / \mathrm{T}_{\mathrm{hNB}}\right)$. The different values relative to $(n)$ ratio are shown in the Table 2.

The average coefficient of consolidation $\left(C_{h}\right)$ in both case (NC) and (NB) were found the same value and independent with $(\mathrm{n})$ ratio, $\mathrm{C}_{\mathrm{hNC}}=\mathrm{C}_{\mathrm{hNB}} \simeq(2 / 3) \mathrm{C}_{\mathrm{hFC}}$.

\subsection{Solution for Axisymetric Unit Cell under Vacuum Combine Surcharge Loading}

In this solution, the surcharge is applied after some degree of consolidation induced by vacuum pressure. 


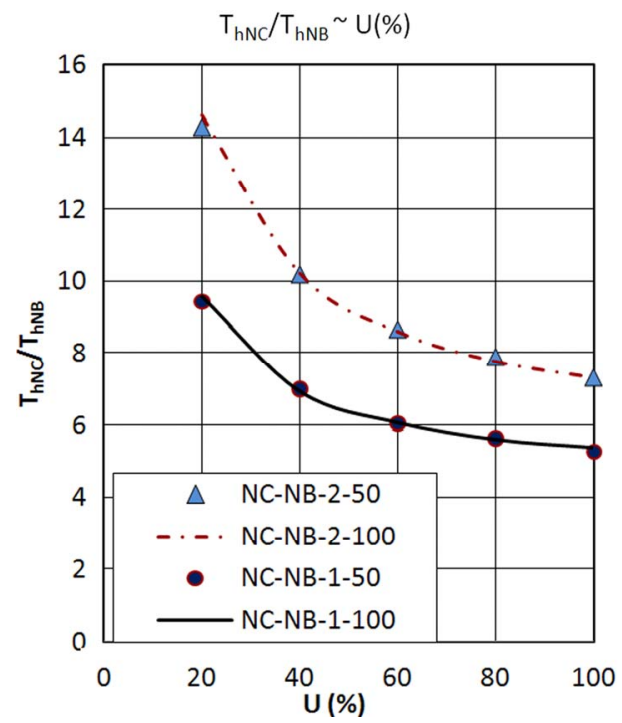

Figure 8. Ratio of time factor $\sim \mathrm{U}(\%)$ for vacuum stage only.

Table 2. The ratio of time factor.

\begin{tabular}{cccccc}
\hline $\mathbf{U}(\mathbf{\%})$ & $\mathbf{2 0}$ & $\mathbf{4 0}$ & $\mathbf{6 0}$ & $\mathbf{8 0}$ & $\mathbf{1 0 0}$ \\
\hline $\mathbf{N}=\mathbf{2 0}$ & 14.6 & 10.2 & 8.57 & 7.76 & 7.31 \\
$\mathbf{N}=\mathbf{1 0}$ & 9.56 & 6.93 & 6.08 & 5.59 & 5.37 \\
\hline
\end{tabular}

Normally, the prefabricated vertical drain (PVD) of dimensions $10 \mathrm{~cm} \times 0.4 \mathrm{~cm}$ is installed by rectangular shape. For this research the equivalent diameter of vertical drain $D_{w}=5 \mathrm{~cm}$ and diameter of cell $D_{e}=100 \mathrm{~cm}$ were used. The example with $\mathrm{D}_{\mathrm{e}}=7.5 \mathrm{~cm}$ and $\mathrm{D}_{\mathrm{w}}=0.3875 \mathrm{~cm}$, and $\mathrm{n}=20$, were used in this analysis and shown in Figure 9. This unit cell also used for modeling the vacuum preloading in the laboratory test.

The surchage stages are applied in three cases of the degree of consolidation (U) reach to $40 \%, 70 \%$ and 100\% as shown in the Table 1.

There are two stages for vacuum preloading method, the first stage is vacuum preloading only until the degree of consolidation reach to the target, and the second stage is surcharge preloading during the vacuum is maintained.

The magnitude and rate of loading determined base on the increasing of effective stress of soil mass.

The surcharge loading estimates equal to $80 \%$ of increase vertical effective stress to prevent the failure state, for each case the loadings are $19.8 \mathrm{kPa}, 29.6 \mathrm{kPa}$ and $42.4 \mathrm{kPa}$ respectively when $50 \mathrm{kPa}$ vacuum pressure is applying.

The loading rate is $0.5 \mathrm{kPa} / \mathrm{min}$ for drainage at the center case (NC), the ration $\mathrm{T}_{\mathrm{hNC}} / \mathrm{T}_{\mathrm{hNB}}$ are used from the Table 2, of 10.2; 8.16 and 7.31 as degree of consolidation $40 \% ; 70 \%$ and $100 \%$ respectively to define the loading rate when the drainage at outer boundary (NB).

The results of relationship between DOC (U) and time factor $T_{h}$ are shown from the Figures 10-12:
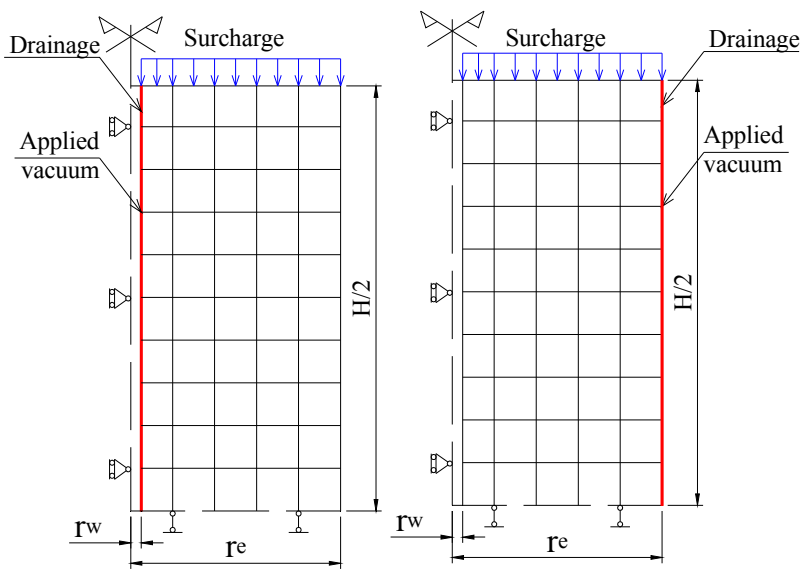

(a)Drainage at center

(b) Drainage at outer boundary

Figure 9. Vacuum combine surchage preloading.

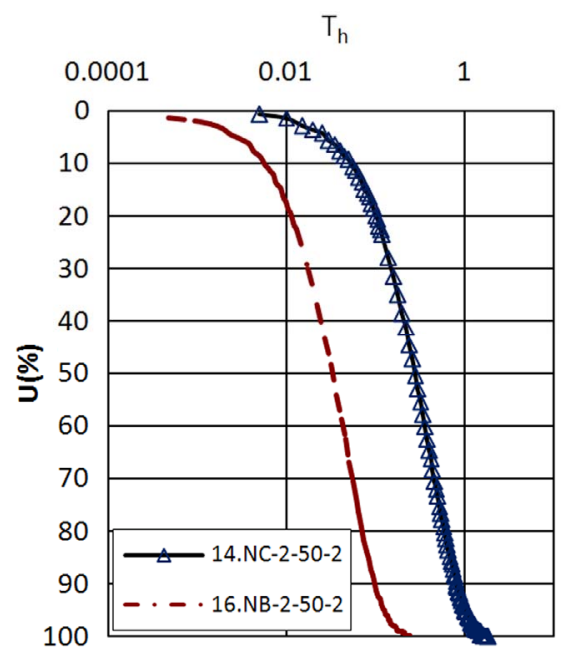

Figure 10. Case $\mathbf{n}=20$, vacuum combine surchage loading; $\mathrm{Va}=50 \mathrm{kPa}, \mathrm{U}=40 \% ; \mathrm{T}_{\mathrm{hNC}} / \mathrm{T}_{\mathrm{hNB}}=8.65$.

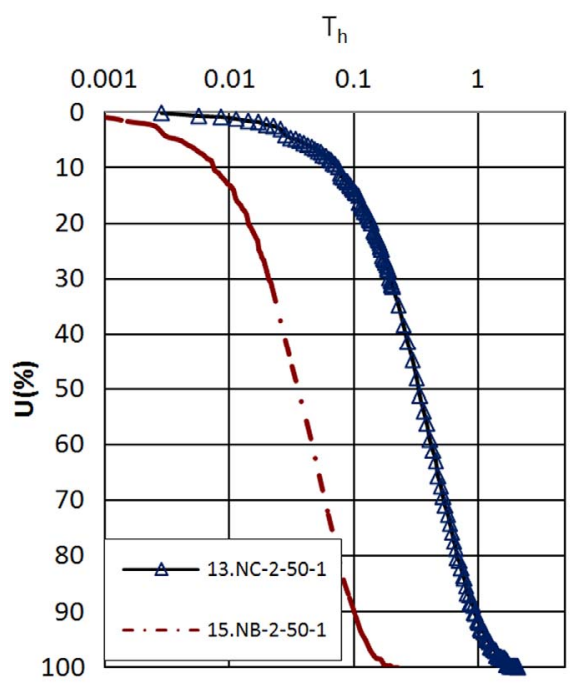

Figure 11. Case $\mathbf{n}=20$, vacuum combine surchage loading; $\mathrm{Va}=50 \mathrm{kPa}, \mathrm{U}=70 \% ; \mathrm{T}_{\mathrm{hNC}} / \mathrm{T}_{\mathrm{hNB}}=8.71$. 


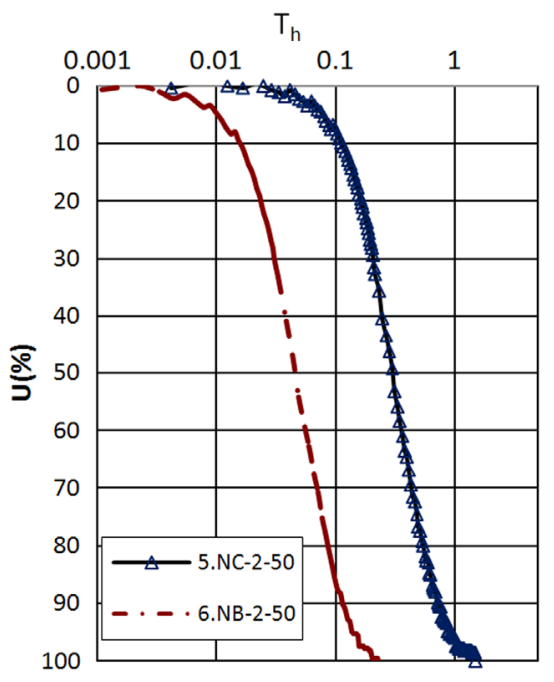

Figure 12. Case $\mathbf{n}=20$, vacuum combine surchage loading; $\mathrm{Va}=50 \mathrm{kPa}, \mathrm{U}=\mathbf{1 0 0} \%$.

From the Figure 13 and Table 3 the average of ratio of time factor are equal to $8.71 \& 8.65$ for vacuum pressure are $100 \mathrm{kPa}$ and $50 \mathrm{kPa}$ respectively, when $\mathrm{U}=$ $100 \%$ the ratio of time factor is nearly same value 7.4 .

In the Figure 14, degree of consolidation at $70 \%$, the maximum different in volume strain is $1.75 \%$ occuring at $420 \mathrm{~min}$ for case $40 \%$ is almost the same in the Figure 15.

From the analyzing above, the final volume strain in case outer boundary is almost same value as that in drainage at the center as surcharge applied at $40 \% ; 70 \%$ and $100 \%$.

Under vacuum $50 \mathrm{kPa}$ and surcharge was applied as degree of consolidation is $100 \%$, the Figure 16 showed the deformation of unit cell (volume strain $\varepsilon_{\mathrm{v}}$ ) during time of vacuum and vacuum combine surcharge are same in two cases (NC) and (NB) after adjustment with the ratio of time factor $\mathrm{T}_{\mathrm{hNC}} / \mathrm{T}_{\mathrm{hNB}}$.

The strain ration $\varepsilon_{\mathrm{r}} / \varepsilon_{\mathrm{a}}$ are the same in both cases and vary from 4 to 1.3 during vacuum stage and reduce to 0.98 during the surcharge was apply. These results are good agreement with vacuum preloading theory, the lateral deformation of embankment is internal during applying vacuum pressure.

The maximum different in volume strain is $2.13 \%$ occurring at $350 \mathrm{~min}$ while the final volume strain is the same in $13.24(\%)$.

These results also agree strongly with the solution in article 2. To make this solution more effectively, the laboratory test by Tri-axial apparatus should be carried out to support this research.

\section{Simulation in Laboratory Test}

\subsection{Soil Specimen}

The serial tests were performed by tri-axial apparatus in

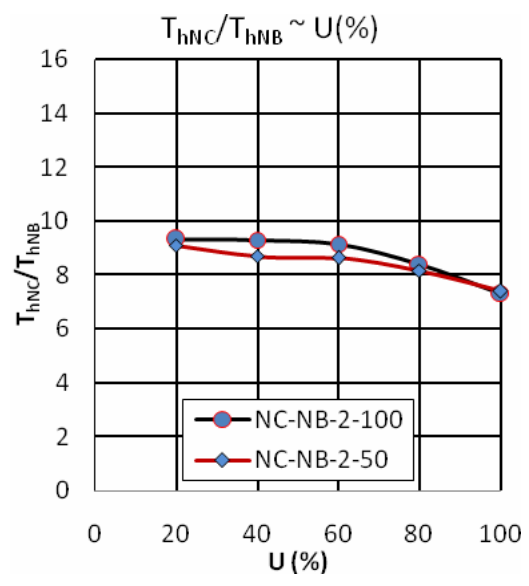

Figure 13. Ratio of time factor $\sim \mathrm{U}(\%)$ for vacuum combine surchage preloading.

Table 3. The ratio of time factor for $n=20$, vacuum combine surchage preloading.

\begin{tabular}{cccccc}
\hline $\mathbf{U}(\%)$ & $\mathbf{2 0}$ & $\mathbf{4 0}$ & $\mathbf{6 0}$ & $\mathbf{8 0}$ & $\mathbf{1 0 0}$ \\
\hline $\mathbf{1 0 0} \mathbf{~ k P a}$ & 9.33 & 9.31 & 9.16 & 8.41 & 7.32 \\
$\mathbf{5 0} \mathbf{~ k P a}$ & 9.10 & 8.70 & 8.63 & 8.17 & 7.41 \\
\hline
\end{tabular}

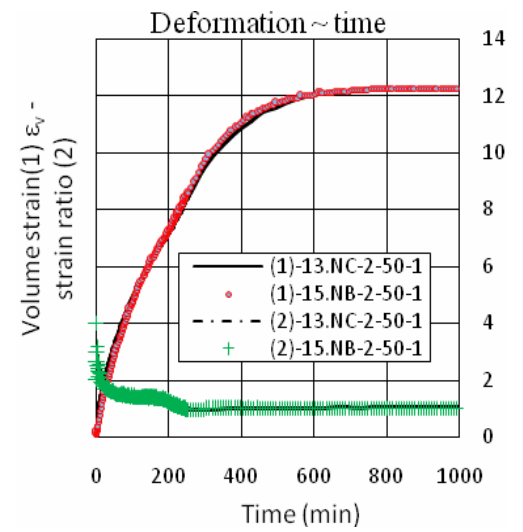

Figure 14. Case $\mathbf{n}=\mathbf{2 0}$, vacuum combine surchage; $\mathrm{Va}=50$ $\mathrm{kPa}, \mathrm{U}=70 \% ; \mathrm{T}_{\mathrm{hNC}} / \mathrm{T}_{\mathrm{hNB}}=8.71$.

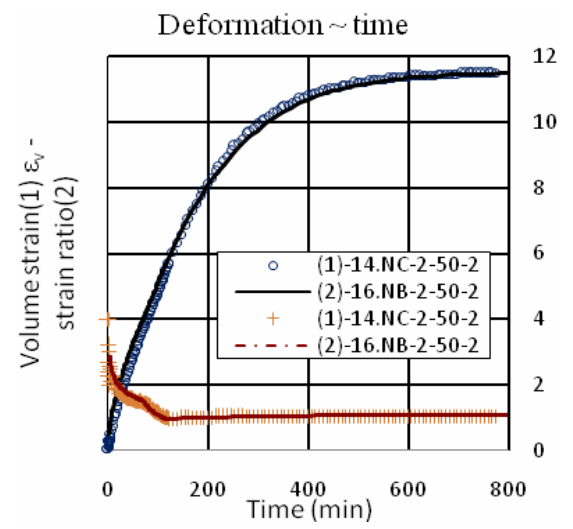

Figure 15. Case $\mathbf{n}=\mathbf{2 0}$, vacuum combine surchage; $\mathrm{Va}=\mathbf{5 0}$ $\mathrm{kPa}, \mathrm{U}=40 \% ; \mathrm{T}_{\mathrm{hNC}} / \mathrm{T}_{\mathrm{hNB}}=8.65$. 


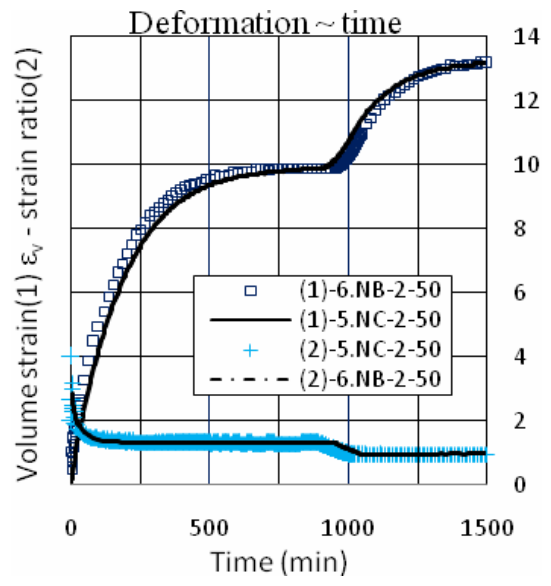

Figure 16. Case $\mathbf{n}=20$, Vacuum combine surchage; $\mathrm{Va}=\mathbf{5 0}$ kPa, $\mathrm{U}=100 \% ; \mathrm{T}_{\mathrm{hNC}} / \mathrm{T}_{\mathrm{hNB}}=7.31$.

the laboratory in Hokkaido University to simulate the behavior of Akasaoka clay improved by vacuum preloading method. The specimens of clay in sizes $75 \mathrm{~mm} \times$ $150 \mathrm{~mm}$ in diameter and height respectively were used for this research, the specimens is suitable to control consolidation time under vacuum condition by tri-axial apparatus, also the retrieved samples from the field. For dummy research specimens were remodel in the laboratory from the commercial Akasaoka clay powder.

The reconstituted Akasaoka clay was pre-consolidated under a pressure of $100 \mathrm{kPa}$ and $\mathrm{OCR}=1.25$, the physical properties of soil are listed in the Table 4 and Figure 17. The permeability coefficient $(\mathrm{k})$ and compression index $(\mathrm{Cc})$ deduced from the standard odometer test result.

The pre-consolidated condition, the effective vertical stress and the effective horizontal stress are $80 \mathrm{kPa}$ and $40 \mathrm{kPa}$ respectively (the coefficient of horizontal earth pressure at rest $\mathrm{K}_{0}=0.5$ ).

Series conventional tri-axial test were carried out to verify the failure line $\left(\mathrm{K}_{\mathrm{f}}\right)$ and relationship between the coefficient $\mathrm{K}$ and the ratio $\mathrm{s}_{\mathrm{u}} / \sigma_{\mathrm{v}}{ }^{\prime}$ as show in Figure 18.

\subsection{Test Procedure}

Before application vacuum pressure, the specimen is saturated with B value more than 0.98 and reach to the initial pre-compression stress with effective vertical and horizontal stress are $80 \mathrm{kPa}$ and $40 \mathrm{kPa}$ respectively after 24 hours (Step loading and recompression step).

The vacuum pressure is simulated by applying the effective stress target with the lateral earth ratio equal to one $(\mathrm{K}=1)$, the soil specimen is subjected the same condition under vacuum pressure as the period research, the behavior of soil mass under surcharge and vacuum pressure is shown in the Figure 19.

While the effective stress is applied, the drainage vale is clocked, under the undrained condition the excess pore water pressure has been increasing up to the vacuum
Table 4. Akasaoka clay's properties.

\begin{tabular}{lc}
\hline Soil properties & Values \\
\hline Unit weight $\left(\mathrm{kN} / \mathrm{m}^{3}\right)$ & 17.5 \\
Water content, w (\%) & 46.5 \\
Liquid limit, wL (\%) & 62 \\
Plastic limit, wP (\%) & 27.5 \\
Plasticity index, PI (\%) & 34.5 \\
Specific gravity, Gs & 2.67 \\
Initial void ratio eo & 1.17 \\
\hline
\end{tabular}

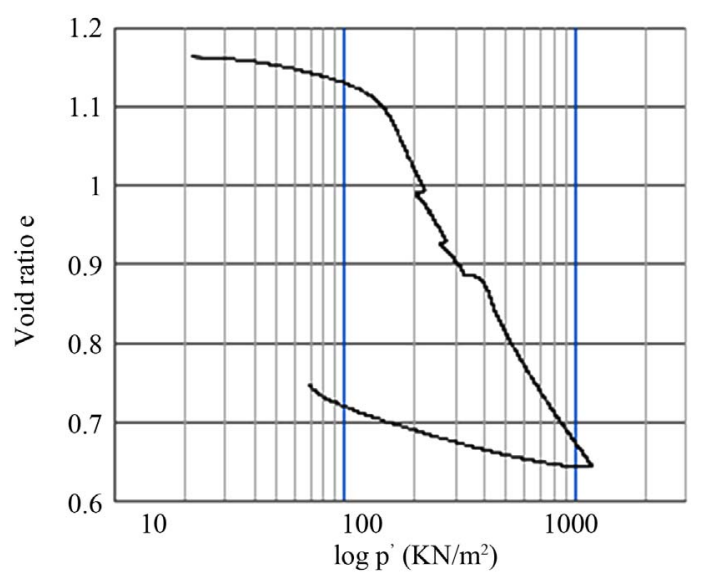

Figure 17. Void ratio $\log \left(p^{\prime}\right)$ graph.

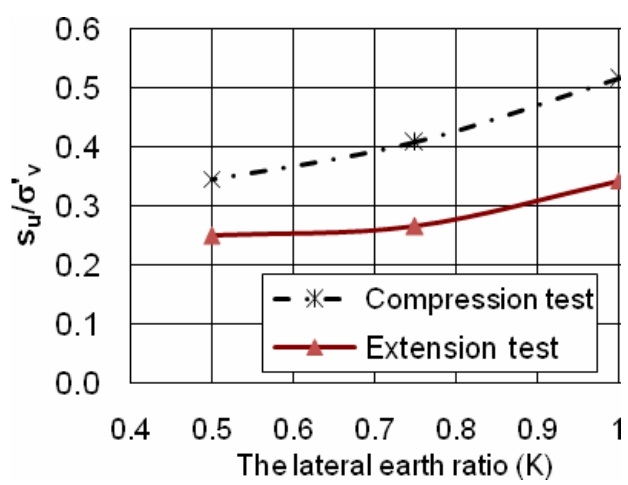

Figure 18. Predict shear strength by effective stress and earth ratio.

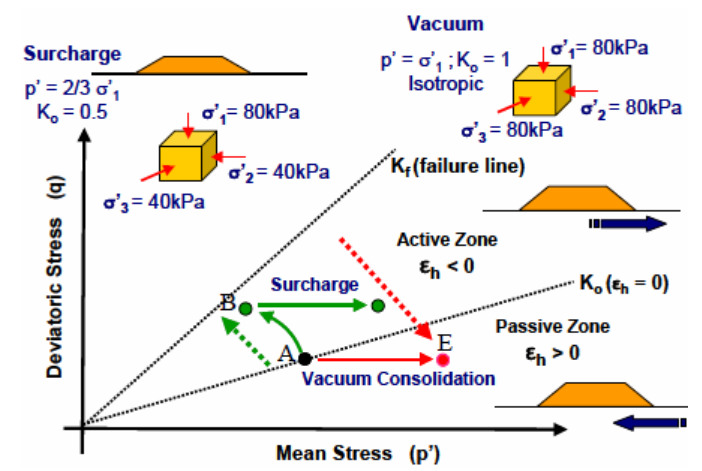

Figure 19. Behavior of soil mass under vacuum and surcharge preloading. 
pressure desired. In the dummy research vacuum pressure, desired are $50 \mathrm{kPa}$ and $100 \mathrm{kPa}$ to concern the depths of specimen there for the total vertical effective stress target of $130 \mathrm{kPa}$ and $180 \mathrm{kPa}$ were generating. (Vacuum pressure supplying step). The parameters in vacuum proceed by tri-axial apparatus are shown in the Table 5 .

The coefficient of horizontal earth pressure $(\mathrm{K})$ is the ratio of the effective horizontal earth pressure due to the confinement from the surrounding soil mass to the vertical effective stress. Then from the Figure 20, $\mathrm{K}$ value can be calculated as follows:

$$
\mathrm{K}=\frac{{\sigma_{3}^{\prime}}_{3}+\sigma_{\text {va }}^{\prime}}{\sigma_{1}^{\prime}+\sigma_{\text {va }}^{\prime}}
$$

During drained progress stage, the consolidation has been occurred due to the excess pore water is dissipated, the effective stress of soil as well as the shear strength will be increase, this behavior is suitable with the vacuum mechanism, and the tri-axial apparatus's gauges record the behavior data and deformation of soil specimen automatically. The soil is consolidated completely when the effective stress increase to the target and the excess pore water dissipates completely. However, from data from FEM and test the times of primary consolidation reach to as the excess pore water pressure dissipates about $95 \%$.

Where:

CP: Cell pressure

BP: Back pressure

PWP: Pore water pressure

$\sigma_{\mathrm{v}}{ }^{\prime}:$ Vertical effective stress target

$\sigma_{\mathrm{h}}{ }^{\prime}$ : Horizontal effective stress target

$\mathrm{K}$ : Coefficient of horizontal earth pressure

The shearing steps are carried out to define the undraind shear strength of soil improved. Depend on the goals these step could be performed at the time after vacuum loading completely or with the increase of degree of consolidation reach to $40 \%, 70 \%, 100 \%$ combine with surcharge to estimate the capacity of soil embankment each construction stage respectively. This step is performed
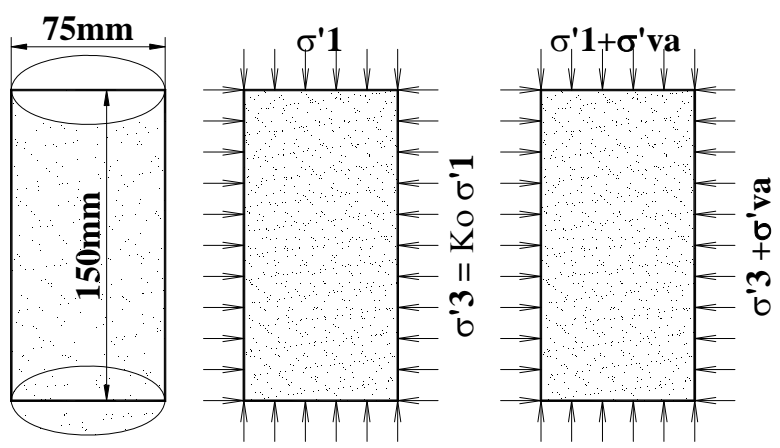

Pre-consolidated,

$\mathrm{OCR}=1.25, \mathrm{k} 0=0.5$

Vacuum condition, $\sigma^{\prime} \mathrm{va}(\mathrm{kPa}), \mathrm{K}$

Table 5. Parameter in vacuum proceed by tri-axial apparatus.

\begin{tabular}{ccccccc}
\hline \multirow{2}{*}{ Step } & $\mathrm{CP}$ & $\mathrm{BP}$ & $\mathrm{PWP}$ & $\sigma_{\mathrm{v}}{ }^{\prime}$ & $\sigma_{\mathrm{h}}{ }^{\prime}$ & $(\mathrm{K})$ \\
\cline { 2 - 7 } & \multicolumn{7}{c}{$(\mathrm{kPa})$} & & & & \\
\hline Step loading & 220 & 200 & 200 & 20 & 20 & 1 \\
Recompression & 240 & 200 & 200 & 80 & 40 & 0.50 \\
Vacuum supplying & 290 & 200 & 250 & 80 & 40 & 0.50 \\
$\begin{array}{c}\text { (50kPa) (Undrained) } \\
\text { Vacuum applied }\end{array}$ & 290 & 200 & 200 & 130 & 90 & 0.692 \\
$\begin{array}{c}\text { Vacuum supplying } \\
(100 \mathrm{kPa}) \text { (Undrained) }\end{array}$ & 340 & 200 & 300 & 80 & 40 & 0.50 \\
Vacuum applied & 340 & 200 & 200 & 180 & 140 & 0.778 \\
\hline
\end{tabular}

to control the surcharge preloading at the site to avoid the soil failed as the surcharge is over the soil capacity as well as instability stage of embankment. The capacity of soil can be predicted by formulation (as empirical method Tanaka):

$$
\mathrm{S}_{\mathrm{u}}=\left(\mathrm{S}_{\mathrm{u}} / \sigma_{v}^{\prime}\right) * 0.8 * \Delta \mathrm{p}
$$

where

$\mathrm{s}_{\mathrm{u}} / \sigma_{\mathrm{v}}$ : determine with the lateral earth ratio $\mathrm{K}$ by the conventional tri-axial test in Figure 18.

$\Delta \mathrm{p}$ : the loading is applied (vacuum pressure or surcharge loading).

The undrain shear strength of soil specimen from lab test result is analysis to check the capacity of soil improved.

\subsection{Test Results and Analysis}

The Figures 21 and 22 are shown the relationship between case (NB) in FEM and lab test, the vacuum $50 \mathrm{kPa}$ was applied only and combination to surcharge respectively. In the both cases the DOC in $100 \%$ were induced, the largest different of $U$ is $3.5 \%$ between FEM and lab test occurring at $\mathrm{T}_{\mathrm{h}}=0.3$.

The final deformation of specimen nearly same value at end of vacuum stage and vacuum combine surcharge as shown in Figure 23. The largest different in volume strain $0.3 \%$ occur at $350 \mathrm{~min}$ as DOC at $95 \%$.

The volume strain in $4.92 \%$ and $7.12 \%$ were found in both cases FEM and Lab Test. The strain ratio $\left(\mathrm{e}_{\mathrm{r}} / \mathrm{e}_{\mathrm{v}}\right)$ illustrated the inward lateral deformation of specimen subjected isotropic stress; this ratio is nearly one during vacuum only and reduces as surcharge was established.

These results agree strongly with behavior of soil improvement by vacuum preloading theory.

The Figure 24 is shown the increasing shear strength of soil specimen before improvement and after application vacuum preloading at several degree of consolidation of $40 \%, 70 \%$ and $100 \%$ respectively.

The stress path is shown in the Figure 25, there are 


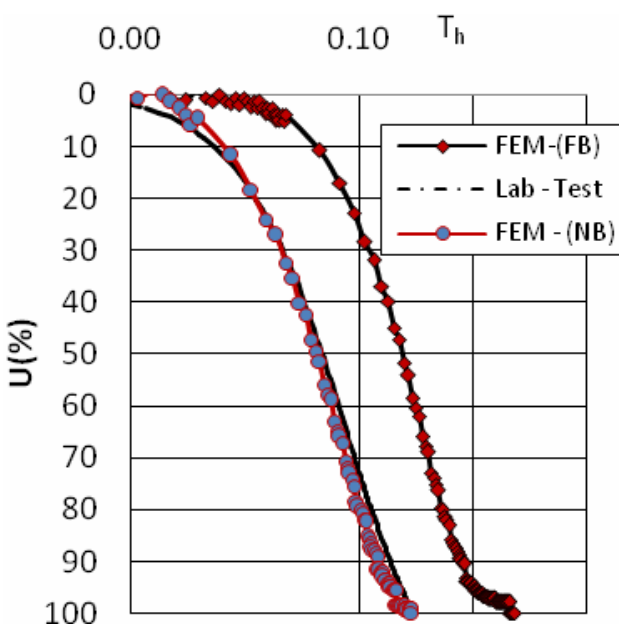

Figure 21. Case $n=20$, vacuum only; $V a=50 \mathrm{kPa}, \mathrm{U}=100 \%$.

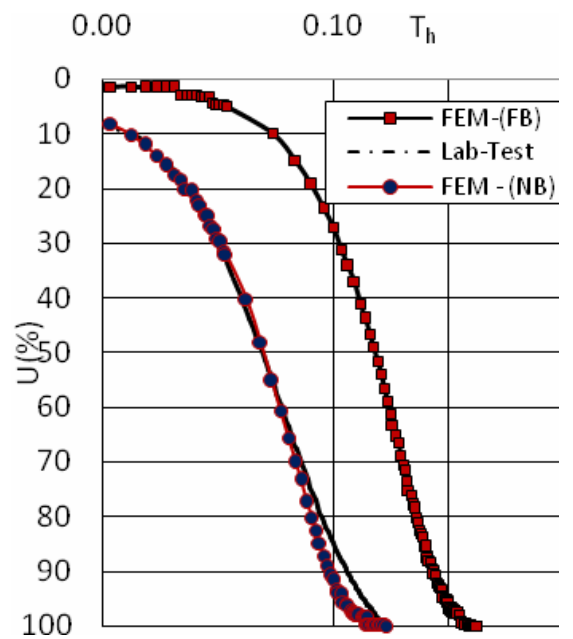

Figure 22. Case $n=20$, vacuum combine surchage; $V a=50$ $\mathrm{kPa}, \mathrm{U}=100 \%$.

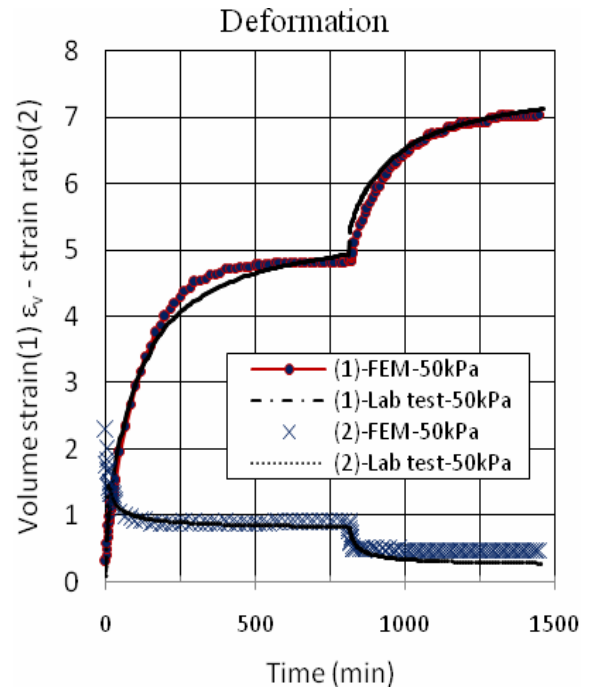

Figure 23. Case $n=20$, vacuum combine surchage; $\mathrm{Va}=\mathbf{5 0}$ $\mathrm{kPa}, \mathrm{U}=100 \%$.

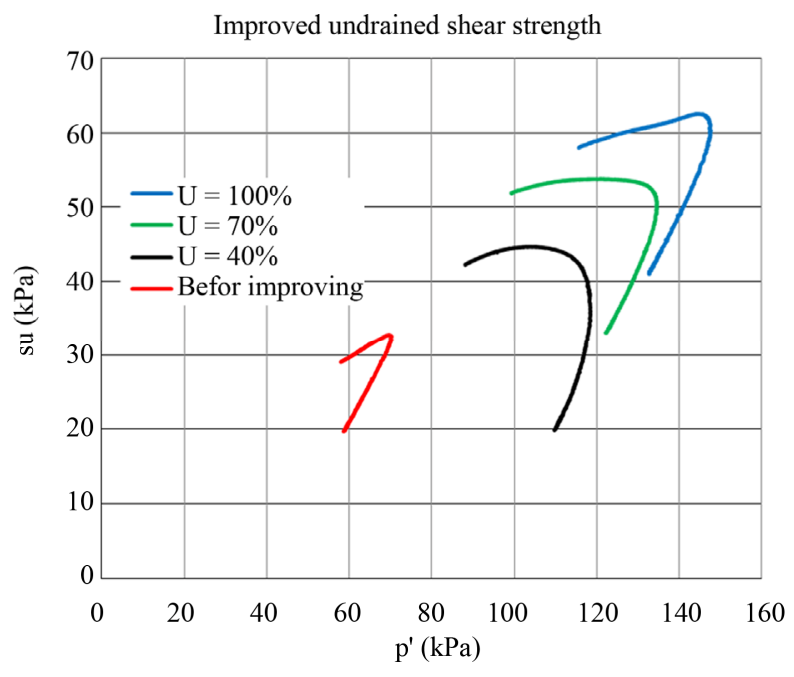

Figure 24. Increasing undrained shear strength.

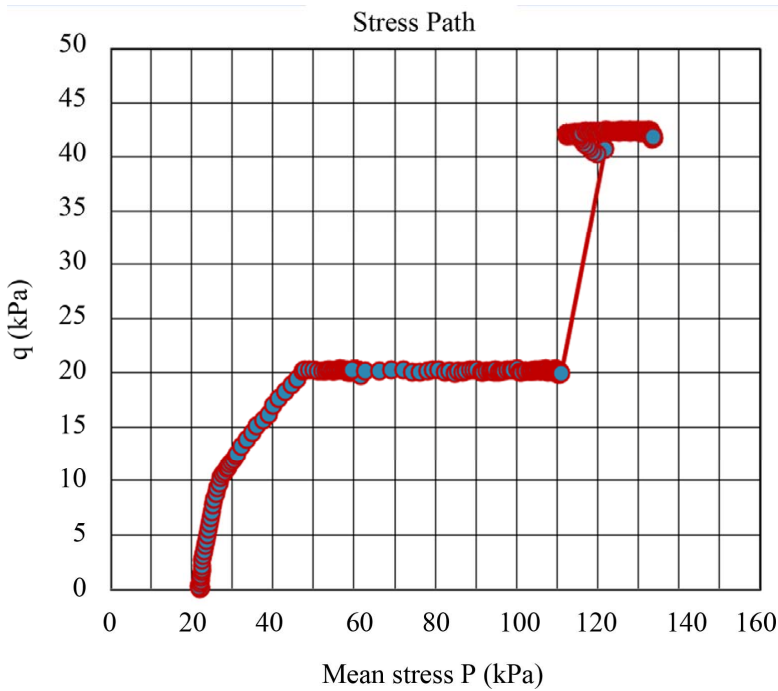

Figure 25. Stress path.

some sections during simulate vacuum preloading method, pre-consolidation $(\mathrm{AB})$, vacuum application $(\mathrm{BC})$, surcharge loading (CDEF). Under vacuum condition, the stress path of soil moves from $\mathrm{B}$ to $\mathrm{C}$ far from the failure line, while it changes from $\mathrm{D}$ to $\mathrm{E}$ close to the failure line when surcharge was applied. The behavior of soil specimen under vacuum preloading method simulated by Tri-axial apparatus is well matched the before studies.

\section{Conclusions}

The study has been developed based on the combination of finite element analysis and the results of laboratory experiments to simulate a new appropriate method. This method can be widely applied for soft ground improvement by vacuum preloading method. The results from the study can be summarized as follows:

1) The axisymetric unit cell used to model the behav- 
ior of soil treatment by vacuum preloading as none boundary conditions are considered, the behavior of soil is more close to real soil state in the field.

2) Two cases of drainages boundary showed that time for consolidation in cases outside drainage of unit cell is faster than at the center by $\mathrm{T}_{\mathrm{hNC}} / \mathrm{T}_{\mathrm{hNB}}$ ratio. However, the deformations of the specimens in all cases are in same shape and value with the same applied condition.

3) Results of experiments by tri-axial apparatus entirely agree with FEM model. It is suggesting that the theories are given full compliance, highly compelling to predict the behavior of soil improvement by vacuum preloading method.

\section{REFERENCES}

[1] W. Kjellman, "Consolidation of Clayey Soils by Atmospheric Pressure," Proceedings of a Conference on Soil Stabilization, Massachusetts Institute of Technology, Boston, 1952, pp. 258-263.

[2] B. Indraratna and I. W. Redana, "Laboratory Determination of Smear Zone Due to Vertical Drain Installation," Journal of Geotechnical and Geoenvironmental Engi- neering, Vol. 124, No. 2, 1998, pp. 180-184. doi:10.1061/(ASCE)1090-0241(1998)124:2(180)

[3] S. Hansbo, "Consolidation of Fine-Grained Soils by Prefabricated Drains," Proceedings of 10th International Conference on Soil Mechanics and Foundation Engineering, Stockholm, Vol. 3, 1981, pp. 677-682.

[4] R. A. Barron, "Consolidation of Fine-Grained Soils by Drain Wells," Transactions of ASCE, Vol. 113, 1948, pp. 718-742.

[5] B. Indraratna, C. Rujikiatkamjorn and I. Sathananthan, "Radial Consolidation of Clay Using Compressibility Indices and Varying Horizontal Permeability," Canadian Geotechnical Journal, Vol. 42, No. 5, 2005, pp. 13301341. doi:10.1139/t05-052

[6] J. C. Chai, J. P. Carter and S. Hayashi, "Vacuum Consolidation and Its Combination with Embankment Loading," Canadian Geotechnical Journal, Vol. 43, No. 10, 2006, pp. 985-996. doi:10.1139/t06-056

[7] T. A. Tran and T. Mitachi, "Equivalent Plane Strain Modeling of Vertical Drains in Soft Ground under Embankment Combined with Vacuum Preloading," Computers and Geotechnics, Vol. 35, No. 5, 2008, pp. 655672. doi:10.1016/j.compgeo.2007.11.006 